\title{
Evaluation of Latent Tuberculosis Prevalence in Chronic Psychotic In-patients
}

Ali ASAN ${ }^{1}$, Sibel YORULMAZ GOKTAS ${ }^{1}$, Hakan DEMIRCI ${ }^{2}$, Ozlem SENGOREN DIKIS ${ }^{3}$, Ibrahim TAYMUR ${ }^{4}$, Mehmet AKTAS ${ }^{5}$, Salih METIN ${ }^{6}$

${ }^{1}$ Department of Infectious Diseases and Clinical Microbiology, University of Health Sciences Turkey Bursa Yuksek Ihtisas Training and Research Hospital, Bursa, TURKEY

${ }^{2}$ Department of Family Medicine, University of Health Sciences Turkey Bursa Yuksek Ihtisas Training and Research Hospital, Bursa, TURKEY

Department of Pulmonary Diseases, University of Health Sciences Turkey Bursa Yuksek Ihtisas Training and Research Hospital, Bursa, TURKEY

${ }^{4}$ Department of Psychiatry, University of Health Sciences Turkey Bursa Yuksek Ihtisas Training and Research Hospital, Bursa, TURKEY

${ }^{5}$ Gursu Zafer Family Health Center, Bursa, TURKEY

${ }^{6}$ Bursa Provincial Health Directorate, Bursa, TURKEY

\begin{abstract}
Aim: Control of risk groups is essential for success in the struggle against tuberculosis. People living in low socioeconomic conditions, in crowded living conditions, in close contact with tuberculosis patients, imprisoned people and health care providers are more at risk compared to other individuals in society. Moreover, at the present time, patients with high hospitalization frequency and psychiatric comorbidities are considered to be in the high risk group for tuberculosis and active screening is recommended. In this study we aimed to determine the rate of latent tuberculosis in a psychotic patient group.

Methods: In the first phase of our descriptive and cross-sectional study, a Tuberculin Skin Test (TST) was performed on psychosis diagnosed patients in our hospital. TST evaluation was done by trained personnel and TST was accepted as positive with $\geq 15 \mathrm{~mm}$ in vaccinated patients and $\geq 10 \mathrm{~mm}$ in unvaccinated patients and was determined to be significant in terms of latent tuberculosis.

Results: The number of PPD positive cases in terms of BCG vaccination status in chronic psychotic and control groups were respectively $66(33.2 \%)$ and $35(16.8 \%)$ and the difference between the two groups was statistically significant $(p=0.001)$. In this study we found that psychotic patients must be carefully considered among risk groups in terms of latent tuberculosis.
\end{abstract}

Keywords: Tuberculosis, risk groups, psychotic disorder

Corresponding Author: Ali ASAN draasan@yahoo.com

Received: April 5, 2021; Accepted:April 6, 2021; Published Online: April 21, 2021

Cite this article as: Asan, A., Yorulmaz Goktas, S., Demirci, H., Sengoren Dikis, O., Taymur, I., Aktas, M. \& Metin, S. (2021). Evaluation of Latent Tuberculosis Prevalence in Chronic Psychotic In-patients. European journal of Human Health 1(1), 34-40. 


\section{Introduction}

Tuberculosis (TB) is an infectious disease caused by Mycobacterium tuberculosis that still constitutes a serious problem worldwide. It is assumed that nearly two billion people (nearly one third of the world population) carry tuberculosis bacillus and thus have a risk of active tuberculosis development at any point in their lives. The World Health Organization (WHO) has declared 6.3 million new tuberculosis cases worldwide in its report in 2017 and it is assumed that it causes the death of nearly 2 million people every year. Tuberculosis is one of the most contagious diseases of today's world together with malaria and HIV and it is ranked $9^{\text {th }}$ among the most common causes of death (1-3). Since it is a preventable cause of death with early diagnosis and treatment, screening and early treatment of risk groups is important (4). The tuberculosis incidence in our country was 14.6 per hundred thousand in 2017 and an average annual decline of $5 \%$ has been observed in the last 10 years. BCG vaccination in childhood still continues in the entire society and screening is also performed for TB high risk groups caused by latent TB infection. Groups with high incidence in our country have been determined as: contacts with TB patients, imprisoned people, health care providers, people with immunosuppressive diseases (AIDS, chronic renal impairment in dialysis, etc.) or patients receiving immunosuppressive treatment (TNF alpha inhibitor users, etc.), and people coming from countries with a high incidence or high rate of drug resistance (5). Moreover, there is a complicated multi-dimensional relationship between psychiatric diseases and tuberculosis and this has been previously discussed in the literature $(6,7)$. The incidence of tuberculosis among psychiatric cases is higher than the normal population. Homelessness, alcohol or substance abuse and HIV comorbidity are common among tuberculosis patients, including psychiatric patients. In addition, the frequency of tuberculosis has increased in refugees among whom psychiatric cases are more common and an aggregation of tuberculosis cases has been observed in refugee groups in countries with a low incidence of tuberculosis (8).

Tuberculosis infection is also termed a latent tuberculosis infection (LTBI). It is diagnosed with a tuberculin skin test (TST) or interferon gamma release assay (IGRA). LTBI is a state of non-active disease without disease symptoms, findings, laboratory or radiology results. The purpose of researching latent tuberculosis infection (LTBI) is to detect individuals with active TB development risk who would profit from LTBI treatment. Although there is no gold standard test in LTBI diagnosis, two tests are used. These are the tuberculin skin test (TST) and the interferon gamma release assay (IGRA). Interferon gamma release assays are the QuantiFERON-TB Gold and TSPOT.TB tests. These tests measure the body's cellular immune response against tuberculosis bacillus. There is no significant difference between IGRAs and TST in terms of their performance in predicting future $T B$ disease (9-11). In cases of cellular immunosuppressing conditions such as HIV infection, the sensitivity of both TST and IGRA decreases. Expertise is needed in applying and reading the TST. Fresh blood is necessary for IGRA and these are more expensive and laboratory requiring tests. The possibility of regular application of tests, their cost and their contribution must be considered in order to decide which test to be used in an institution or TB control program in a country $(5,12,13)$.

TB incidence is high in chronic psychotic in-patients compared to the general population, especially due to living in a limited space $(6,14,15)$. The aim of this study was also to contribute to public health through screening chronic psychotic in-patients with TST and evaluating the positive cases in terms of treatment. 
The limitation of the study was the use of TST in screening. The sensitivity of TST may especially decrease with factors such as previous BCG vaccination or exposure to non-tuberculosis mycobacterium (12).

\section{Materials \& Methods}

In the first phase of our descriptive and cross-sectional study the Tuberculin Skin Test (TST) was applied to patients who had a chronic psychosis diagnosis and were treated as in-patients in the psychiatry service of our hospital. In the second phase, patients who had been previously hospitalized and followed-up in the psychiatry service and then discharged were called by phone and those who accepted to have a TST were invited to the psychiatry outpatient clinic and the TST was given. A sample selection was not made as the aim was to reach all of the patients.

In the TST application, $0.1 \mathrm{ml}$ of purified protein derivative (PPD) equivalent to 5 tuberculin units obtained from $M$. tuberculosis was injected intradermally on the flexor surface of the left forearm with an insulin injector (Mantoux technique) (16). TST was performed by a health care personnel trained on this subject. The induration across the forearm was evaluated in millimeters, 72 hours after the TST. In TST evaluation we used the criteria in table-1 (16).

Table 1. TST evaluation criteria in our country (5)

\begin{tabular}{|l|l|}
\hline Vaccinated & Unvaccinated \\
\hline$\leq 5 \mathrm{~mm}$ Negative & $\leq 5 \mathrm{~mm}$ Negative \\
\hline $6-14 \mathrm{~mm}$ depending on vaccine & $\begin{array}{l}6-9 \mathrm{~mm} \text { suspicious, TST will be repeated after } 1 \text { week; negative if } 6-9 \\
\text { mm again; positive if equals to or greater than } 10 \mathrm{~mm}\end{array}$ \\
\hline$\geq 15 \mathrm{~mm}$ Positive & $\geq 10 \mathrm{~mm}$ Positive \\
\hline
\end{tabular}

\section{Statistical Analysis}

Data were evaluated with IBM SPSS version 21.0 (SPSS; IBM Corporation, New York US) program. Chisquare test as a non-parametric test and a parametric t-test were used. $\mathrm{P}$ value $<0.05$ was accepted as significant.

\section{Results}

408 patients in total were included in our study, 200 of which were chronic psychotic patients and 208 were the control group. $71.6 \%$ of the study population was male and the mean age was $37.75 \pm 12.93$ (range 1868) (Table-2).

The mean ages of the chronic psychotic patients and the control group were respectively $37.4 \pm 12.87$ and $38.08 \pm 13.00, p=0.59$. The male patient population and percentage were $145(72.5 \%)$ in the chronic psychotic group and 147 (70.7\%) in the control group $(p=0.68)$ (Table-2). 
Table 2. Demographic characteristics of the study population

\begin{tabular}{|c|c|c|c|c|}
\hline & All patients & Psychiatric disorder & Control group & $\mathrm{p}$ value \\
\hline Patients, $\mathrm{n}$ & 408 & 200 & 208 & \\
\hline Gender, F/M, n (\%) & $116 / 292(28.4 / 71.6)$ & $55 / 145(27.5 / 72.5)$ & $61 / 147(29.3 / 70.7)$ & 0.383 \\
\hline $\begin{array}{l}\text { Age, n }(\%) \\
\leq 19 \\
20-29 \\
30-39 \\
40-49 \\
50-59 \\
\geq 60\end{array}$ & $\begin{array}{l}16(3.9) \\
117(28.7) \\
109(26.7) \\
93(22.8) \\
41(10.0) \\
32(7.8)\end{array}$ & $\begin{array}{l}8(4.0) \\
58(29.0) \\
53(26.5) \\
48(24.0) \\
17(8.5) \\
16(8.0)\end{array}$ & $\begin{array}{l}8(3.9) \\
59(28.4) \\
56(26.9) \\
45(21.6) \\
24(11.5) \\
16(7.7)\end{array}$ & 0.942 \\
\hline $\begin{array}{l}\text { Working status, n (\%) } \\
\text { Working } \\
\text { Unemployed } \\
\text { Retired }\end{array}$ & $\begin{array}{l}135(64.9) \\
72(34.6) \\
1(0.5)\end{array}$ & $\begin{array}{l}54(27.0) \\
146(73.0) \\
0(0)\end{array}$ & $\begin{array}{l}135(64.9) \\
72(34.6) \\
1(0.5)\end{array}$ & 0.001 \\
\hline $\begin{array}{l}\text { Marital status, n (\%) } \\
\text { Married } \\
\text { Single } \\
\text { Divorced }\end{array}$ & $\begin{array}{l}181(44.4) \\
196(48.0) \\
31(7.6)\end{array}$ & $\begin{array}{l}38(19.0) \\
137(68.5) \\
25(12.5)\end{array}$ & $\begin{array}{l}143(68.8) \\
59(28.4) \\
6(2.8)\end{array}$ & 0.001 \\
\hline $\begin{array}{l}\text { Educational status } \\
\text { Illiterate } \\
\text { Literate/primary school } \\
\text { Middle /high school } \\
\text { College }\end{array}$ & $\begin{array}{l}15(3.7) \\
129(31.6) \\
170(41.7) \\
94(6.0)\end{array}$ & $\begin{array}{l}11(5.5) \\
72(36.0) \\
105(52.5) \\
12(23.0)\end{array}$ & $\begin{array}{l}4(1.9) \\
57(27.4) \\
65(31.3) \\
82(39.4)\end{array}$ & 0.001 \\
\hline
\end{tabular}

A BCG scar was detected on the arms of 155 (77.5\%) of the chronic psychotic patients, whereas there was a BCG scar for 147 (89.9\%) individuals in the control group, and the difference between them was statistically significant $(p=0.001)$. The number of patients with positive PPD results in terms of BCG presence in the chronic psychotic and control groups were $66(33.2 \%)$ and $35(16.8 \%)$ respectively and the difference between them was statistically significant $(p=0.001)$. The PPD result was zero in $32(16.1 \%)$ patients in the chronic psychotic group and this figure was $18(8.7 \%)$ in the control group. The difference was statistically significant $(p=0.02)($ Table-3).

Table 3. Medications used by chronic psychotic patients and PPD positivity

\begin{tabular}{|l|l|l|l|}
\hline Medications & $\mathrm{n}(\%)$ & PPD positive $(\%)$ & P value \\
\hline Lorazepam & $73(36.5 \%)$ & $25(34.2 \%)$ & 0.86 \\
\hline Olanzapine & $49(24.5 \%)$ & $17(34.6 \%)$ & 0.96 \\
\hline Biperiden & $47(23.5 \%)$ & $16(34.0 \%)$ & 0.87 \\
\hline Risperidone & $39(19.5 \%)$ & $13(33.3 \%)$ & 0.82 \\
\hline Quetiapine & $29(14.5 \%)$ & $8(27.5 \%)$ & 0.35 \\
\hline Amisulpride & $23(11.5 \%)$ & $7(31.8 \%)$ & 0.73 \\
\hline Haloperidol & $20(10 \%)$ & $3(15.0 \%)$ & 0.04 \\
\hline Clozapine & $19(9.5 \%)$ & $10(52.6 \%)$ & 0.08 \\
\hline
\end{tabular}


When the medications used in the treatment of chronic psychotic patients were assessed, 73 (36.5\%) patients were using lorazepam, 49 (24.5\%) patients were using olanzapine and 39 (19.5\%) were using risperidone. In terms of PPD positivity, PPD was significantly positive only in patients using haloperidol $(p=0.04)($ Table-4).

Table 4 Patients with BCG scar

\begin{tabular}{|l|l|l|}
\hline & Psychiatric disorder & Control group \\
\hline Patients, $\mathrm{p}$ & 200 & 208 \\
\hline Gender, M/F, $\mathrm{n}(\%)$ & $55 / 145(27.5 / 72.5)$ & $61 / 147(29.3 / 70.7)$ \\
\hline Age (mean \pm SD) & $37.40 \pm 12.87$ & $38.08 \pm 13.00$ \\
\hline PPD negative, $\mathrm{n}(\%)$ & $32(16.1)$ & 0.68 \\
\hline BCG scar presence n (\%) & $155(77.5)$ & $18(8.7)$ \\
\hline PPD positivity is significant n $(\%)$ & $66(33.2)$ & $\mathbf{0 . 0 2}$ \\
\hline
\end{tabular}

\section{Discussion}

In this study performed with 200 chronic psychosis diagnosed patients who had been hospitalized and treated in our hospital, some being discharged, and 208 control group patients, the presence of psychosis was significant compared to the control group in terms of latent TB. In our study, the rate of PPD positive chronic psychotic patients was $33.2 \%$ and this result was similar to the results of the study on psychiatric patients (36.7\%) performed by Saez et al. (17) in New York. Similarly, in a study in which 257 chronic psychosis diagnosed in-patients were given a PPD test and latent tuberculosis screening was performed, the PPD positivity rate was $32.3 \%$ (1). In another study, the tuberculin skin test was given to 71 psychiatry patients and the result was positive in 12 patients $(17 \%)$. Most of the patients with latent tuberculosis were immigrants and they presented additional risk factors as well $(18,19)$.

It is assumed that living conditions and socioeconomic factors also have an effect on latent TB development in chronic psychosis patients (3). In our study, the number of unemployed patients was significantly higher in the psychotic group $(p=0.001)$. Similarly, the number of unmarried patients in the psychotic patient group was significantly higher (Table-1)

In our study, the relationship between medications used in the treatment of chronic psychotic patients and PPD positivity has also been researched and when patients using lorazepam, olanzapine, risperidone and haloperidol were assessed in terms of PPD positivity, PPD was significantly positive only for the patients using haloperidol. We have not encountered a study in the literature claiming that antipsychotic medications increase the risk of tuberculosis. There are studies on the antituberculosis effect only of thioridazine among antipsychotic medications (21).

Some inconsistencies between Quantiferon-TB test and TST results have been reported in countries where BCG vaccination is extensively used. In a study conducted with healthcare workers in Japan, the TST positivity was $93.1 \%$ and the Quantiferon-TB test positivity was $9.9 \%$ (21). The BCG vaccination rate in the population was reported as $95 \%$. Similarly, in our study PPD positivity increased significantly with BCG vaccination status, nevertheless the figure was significantly higher compared to the control group who had a BCG vaccine $(p=0,001)$.

Although IGRA tests are recommended as the first option in latent TB diagnosis by the IDSA 2017 TB 
diagnosis guide in children and adults, the PPD test is also recommended due to its cost-efficiency and easier accessibility, when it is performed by authorized personnel (22). A study was conducted in Turkey with 166 schizophrenia patients comparing Quantiferon-TB Gold and TST, and the tests were found to be comparable (13). Moreover, screening studies are also conducted on patients with psychotic disorders with chest radiography (23). Further screening studies could not be performed due to cost and adaptation difficulties in the psychotic patient group. Comparative latent TB diagnosis tests need to be conducted with larger patient groups, and further screening studies in terms of active TB are necessary in patients with latent TB. However, we assume that our study is significant in the sense of consideration of psychotic patients as a risk group for latent TB. These patients, who frequently require hospitalization, need to be screened in terms of latent TB for the public health.

\section{Conflict of interest}

The authors declare that there is no conflict of interest.

\section{References}

1. Ebrahimi $\mathrm{H}$, Modabbernia MJ, Mohammadi $A$, Jahromi SK, Naghdipour M, Ebrahimi $H$. Frequency of latent and smear positive tuberculosis in chronic psychotic disorders. Iran J Psychiatry. 2013 Mar;8(1):51-4.

2. World Health Organization. Global tuberculosis report 2017. Genova: WHO 2017 http://www.who.int/tb/publications/global_rep ort/MainText_13Nov2017.pdf, accessed 18 March 2021)

3. Kuo SC, Chen YT, Li SY, Lee YT, Yang AC, Chen $\mathrm{TL}_{\text {, Liu } \mathrm{CJ}}$, Chen TJ, Su IJ, Fung CP. Incidence and outcome of newly-diagnosed tuberculosis in schizophrenics: a 12-year, nationwide, retrospective longitudinal study. BMC Infect Dis. 2013 Jul 29;13:351.
4. Fauci A, Braunwald E, Kasper D, Hauser S, Longo D, Jameson J, et al. Harrison's principles of Internal Medicine, 17eds. United State: McGraw-Hill; 2008.

5. Tüberküloz Tanı ve Tedavi Rehberi. Sağlık Bakanlığı Yayın No: 1129. Ankara: Artı6 Medya Tanıtım Matbaaclık; 2019.

6. Doherty AM, Kelly J, McDonald C, O'Dywer AM, Keane J, Cooney J. A review of the interplay between tuberculosis and mental health. Gen Hosp Psychiatry. 2013 Jul-Aug;35(4):398-406.

7. Friedman LN, Sullivan GM, Bevilaqua $R$ et al: Tuberculosis screening in alcoholics and drug addicts. Annual Review of Respiratory Disease 136:1188-1192, 1987

8. Martens WH. A review of physical and mental health in homeless persons. Public Health Rev 2001;29(1):13-33

9. Diel R, Loddenkemper R, Meywald-Walter K, et al. Predictive value of a whole blood IFNgamma assay for the development of active tuberculosis disease after recent infection with Mycobacterium tuberculosis. Am J Respir Crit Care Med 2008; 177:1164-70.

10. Centers for Disease Control and Prevention, Division of Tuberculosis Elimination. List of Major Errata in Order of Importance from the "Guidelines for Preventing the Transmission of Mycobacterium tuberculosis in Health-care Settings, 2005." September 25, 2006:[1-17]. http://www.cdc.gov/nchstp/tb/pubs/mmwrhtm // errata09-25-06.pdf 321 19. Kaynaklar 19

11. World Health Organization. WHO policy on TB infection control in health-care facilities, congregate settings and households. 2009: [139 ve ekler bölümü]. WHO/HTM/TB/2009.419

12. Auguste $P$, Tsertsvadze A, Pink J, et al. Comparing interferon-gamma release assays with tuberculin skin test for identifying latent tuberculosis infection that progresses to active tuberculosis: systematic review and metaanalysis. BMC Infect Dis 2017; 17: 200.

13. Çetin EA, Çiftçi $F$, Gülöksüz $S$, Köksalan $K$, Sezer O, Oral ET, Çetin T, Kurt E, Kaya H, Deniz G. Psikiyatri Kliniklerinde Yapılan Latent Tüberküloz Enfeksiyonu Taramalarında QuantiFERON-TB Gold Testi Tüberkülin Deri Testine Göre Daha Avantajlı Olabilir. Balkan Med J 2012; 29: 115-6.

14. McQuistion HL, Colson $P$, Yankowitz R, Susser $E$. Tuberculosis infection among people with 
severe mental illness. Psychiatr Serv. 1997 Jun;48(6):833-5.

15. Yolken RH, Torrey EF. Infections agents and gene-environmental intractions in the etiopathogenesis of schizopherenia, Association for Research in Nervous and Mental Disease. Elsevier B.V: 2006

16. Kılınç, O. tüberkülin deri testi (TDT), yorumu ve son gelişmeler. 21. Yüzyılda Tüberküloz Sempozyumu ve II. Tüberküloz Laboratuvar Tanı Yöntemleri Kursu, Samsun

17. Saez H, Valencia E, Conover S, Susser E. Tuberculosis and HIV among mentally ill men in a New York City shelter. Am J Public Health 1996;86(9):1318-9.

18. Colson P Susser E, Valencia E. HIV and TB among people who are homeless and mentally ill. Psychosocial Rehabilitation Journal 17:157160,1994

19. van Hest R, Story A. Tuberculosis control in homeless persons in European Union: more than words alone. Pneumologia. 2009 AprJun;58(2):84-7.
20. Amaral L, Viveiros M. Thioridazine: A nonantibiotic drug highly effective, in combination with first line anti-tuberculosis drugs, against any form of antibiotic resistance of mycobacterium tuberculosis due to its multimechanisms of action. Antibiot (Basel) (2017) $6: 3$.

21. Hung WT, Lee SS, Sy CL, Wu KS, Chen JK, Tsai $\mathrm{HC}$, Chen YS. Prevalence of latent tuberculosis infection in BCG-vaccinated healthcare workers by using an interferongamma release assay and the tuberculin skin test in an intermediate tuberculosis burden country. J Microbiol Immunol Infect. 2015 Apr;48(2):147-52.

22. Lewinsohn DM, Leonard MK, LoBue PA, et al. Official American Thoracic Society/Infectious Diseases Society of America/Centers for Disease Control and Prevention clinical practice guidelines: diagnosis of tuberculosis in adults and children. Clin Infect Dis2017; 64:e1-33.

23. Borzenko AS, Zubova E, Laitskii Iu A. Detection of pulmonary tuberculosis in patients with mental disorders. Probl Tuberk Bolezn Legk 2008: $10-12$ 